\title{
Urban resilience thinking in practice: ensuring flows of benefit from green and blue infrastructure
}

\author{
Erik Andersson $^{1,2}, \underline{\text { Sara Borgström }}^{3}, \underline{\text { Dagmar Haase }}^{4,5}, \underline{\text { Johannes Langemever }}^{4,6}$, Manuel Wolff $^{4,7}$ and $_{\text {Timon McPhearson }^{1,8,9}}$
}

ABSTRACT. Present and future urbanization together with climate change and other uncertainties make urban quality of life a critical issue, and one that will need constant attention and deliberation. Across cities and contexts, urban ecosystems in the form of green and blue infrastructure, have the potential to contribute to human well-being as well as supporting biodiversity, and to do so under diverse conditions. However, the realization of this potential depends not only on the green and blue infrastructure itself, the well-being benefits are outcomes of the structures and processes of the entire urban system. Drawing on theory and insights from social-ecologicaltechnological systems (SETS) research and resilience assessments, we describe how a systemic understanding of the generation and delivery of green and blue infrastructure benefits may inform cross-sectoral strategies and interventions for building resilience around this particular aspect of human well-being. Connecting SETS to non-academic discourse and practice, we describe the urban system in terms of three systemic controlling variables: infrastructure, institutions, and the perceptions of individual beneficiaries, which we call filters, and how these can be used in different participatory processes to assess and build resilience around green and blue infrastructure and its benefits.

To ground the conceptual and theoretical framework in real world complexity and make it operational in practice we discuss three case studies applying the framework in Barcelona, Halle, and Stockholm. All cases share the same general three-step process but their individual combinations of methods and adaptions of the filters framework are designed to fit with three necessarily unique collaborative, transdisciplinary processes. The cases are discussed in terms of outcomes and output, the ways they made use of the conceptual framework, and the challenges they faced. This exploratory work points to a new way of engaging with urban resilience- the strength of the approach is that it is not limited to the identification of specific interventions or policy options, nor trying to prevent change; rather it focuses on how to move with change and build resilience through constant balancing of different types of SETS change. Our study reinforces the growing understanding of how well-being benefits positioned as emergent outcomes of internal SETS interactions offers leverage for mainstreaming green and blue infrastructure throughout diverse governance processes and sectors.

Key Words: complex adaptive systems; knowledge co-creation; participatory processes; social-ecological-technological systems; solutionoriented research

ENABLING AND ENSURING URBAN GREEN AND BLUE INFRASTRUCTURE BENEFITS

Worldwide, cities face rapid changes in natural hazards, resident mobility, urban densification, sprawl or shrinkage, demographics, and lifestyles, all potentially affecting the access to the different services and resources necessary for good quality of life. Although there are many reasons for the ongoing global aggregation of people in cities, compact, built-up, and sealed spaces, high population densities, and intensive resource use pose a challenge to both health and well-being of city residents (Elmqvist et al. 2018a, 2021, McPhearson et al. 2021). Externalized support systems for satisfying many basic human needs of food and other environmental goods (Seto et al. 2012, Friis and Nielsen 2019) cannot solve all urban challenges in terms of environmental quality. For example, localized, and often locally caused environmental burdens (particles, noise, waste, soil and water contamination, heat island, flooding) threaten to seriously hamper the overall positive development of human health and well-being, as do more sedentary lifestyles (e.g., Tzoulas et al. 2007, van den Bosch and Sang 2017). Green and blue infrastructure $(\mathrm{GBI})$, or the many different urban ecosystems and the ecosystem services (ES) they may provide for urban residents, is a core asset for improving, mitigating, or reducing many of these urban problems and vulnerabilities (e.g., Gómez-Baggethun et al. 2013, Haase et al. 2014, McPhearson et al. 2015). Although in theory greener cities have a broad general societal support, the reality of competing land uses, preferences for different urban amenities, diverging economic interests, and limitations to the mandate, resources, and policy instruments of local authorities have led to increasing pressures on GBI (e.g., Haase et al. 2017) rather than its expansion or improved quality. Moreover, even in city regions with extensive GBI, realizing well-being benefits can be challenging, at least for some social groups, because green spaces are subject to social conflicts and mental barriers (e.g., Seymour 2012, Rigolon 2016).

A fundamentally complex issue like sustained urban quality of life for all, through ever-changing interactions between urban residents and GBI requires a sophisticated understanding of the urban system. To be practically applicable, though, frameworks and approaches need to be simple and adaptable for working within existing governance structures and processes. Similar to

${ }^{1}$ Stockholm Resilience Centre, Stockholm University, Stockholm, Sweden, ${ }^{2}$ North-West University, Unit for Environmental Sciences, Potchefstroom, South Africa, ${ }^{3}$ Department of Sustainable Development, Environmental Science and Engineering, KTH Royal Institute of Technology, Stockholm, Sweden, ${ }^{4}$ Department of Geography, Humboldt-Universität zu Berlin, Germany, ${ }^{5}$ Department of Computational Landscape Ecology, Helmholtz Centre for Environmental Research - UFZ, Leipzig, Germany, ${ }^{6}$ Institute of Environmental Science and Technology (ICTA), Universitat Autònoma de Barcelona, Barcelona, Spain, ${ }^{7}$ Department of Urban and Environmental Sociology, Helmholtz Centre for Environmental Research - UFZ, Leipzig, Germany, ${ }^{8}$ Urban Systems Lab, The New School, New York, NY, USA, ${ }^{9}$ Cary Institute of Ecosystem Studies, Millbrook, NY, USA 
other "wicked problems" (cf. Rittel and Webber 1973), there is an ongoing discussion about what the problem is about (physical green spaces or the actual benefits they may or may not provide for different beneficiaries), and how and by whom problems should be addressed (e.g., Lang et al. 2012, Turnhout et al. 2020). Thus, there are no straightforward, simple or universal solutions to ensuring urban quality of life. In response to the complex nature of the problem, theory and practice around urban resilience is receiving increasing interest and has become a major talking point within academia as well as outside (e.g., Pu and Qiu 2016, Elmqvist et al. 2019). However, the meaning and hence the usefulness of the concept is still intensively discussed and its application in policy remains inconsistent and potentially confusing (e.g., Meerow et al. 2016, Elmqvist et al. 2019, Edwards 2020). Plural meanings and sometimes a high level of abstraction makes it difficult to use resilience as an analytical tool or as an instrument for guiding the practice of sustainable development (Enfors-Kautsky et al. 2018, Romice et al. 2018, Sellberg et al. 2018). Although there is a value in plurality and not too narrowly defining resilience, we still see a need for more operational approaches for applying resilience and the theories behind the concept.

Portraying resilience as the capacity of a system to absorb disturbance, reorganize, and retain essentially the same functions over time (in line with Elmqvist et al. 2019), we show how a socialecological-technological systems (SETS; sensu Grimm et al. 2016, McPhearson et al. 2016, 2021, Markolf et al. 2018) approach to resilience thinking in combination with transdisciplinary knowledge co-creation processes can be applied to investigate and build resilience around the generation and use of diverse GBI benefits (more details on our use of resilience can be found in Appendix 1). Our work provides, first, a brief description of our urban SETS conceptualization informed by resilience theory where generation and flow of GBI benefits are enabled or hindered by the composition and dynamics of the larger urban SETS. Second, we describe and discuss how we used the framework to guide three transdisciplinary case studies. We draw on the insights from these cases and multi-step processes to distil recommendations for future research as well as the practical application of the framework for building resilience around GBI benefits. Rather than converging on a more specific version of the conceptual framework, we use the cases to illustrate the need for flexibility and context-sensitive application, and how a conceptual framework evolves through case-specific deliberations.

\section{CONCEPTUALIZATION: GBI BENEFITS AS EMERGENT PROPERTIES OF SETS}

We propose that actively working with system level filters (sensu Andersson et al. 2019) offers a way for building resilience around the flow of GBI benefits, which we identify as a core contribution to overall urban resilience. However, for successful real world application, SETS theory needs to connect to non-academic discourse and practice (McPhearson et al. 2021). Our SETSgrounded framework positions GBI as placed primarily in the ecological domain, although humans are actively part of the ecological dynamics through their use and management of GBI. Furthermore, we recognize the co-creation and distribution of diverse GBI benefits as a context-sensitive issue, embedded and enmeshed in social and technological facets of cities and urban life (Ernstson 2013, Andersson et al. 2015, Palomo et al. 2016,
Juntti and Lundy 2017). To make SETS more operational, we follow a recommendation from resilience theory (cf. the recommended "3-5 key factors" for defining a state, Resilience Alliance 2010): Walker and colleagues (2012) point to the importance of controlling variables, the core features that over time shape and change the overall identity of the system. Given the focus of this study, the generation and flow of GBI benefits, we argue that three filters-physical infrastructure, societal institutions, and human perceptions and capacities - may serve as the controlling SETS variables in a sufficiently reductionistwhile-embracing-complexity system framing. All three "are objects which are both plastic enough to adapt to local needs and the constraints of the several parties involving them, yet robust enough to maintain a common identity across sites. [...] They have different meanings in different social worlds [and across cultures] but their structure is common enough to more than one world to make them recognizable, a means of translation." (Star and Griesemer 1989:393, see also Turnhout 2009; Box 1.). Hence, these three filters serve as our operational version of SETS.

\section{Box 1: Three filters}

The three filters are not only controlling variables, but are also, to a certain extent, controllable. Especially the first two are traditional targets for urban planning and governance. Infrastructure has been repeatedly demonstrated as highly relevant for connecting ES supply and demand, and it has multiple additional functional linkages to ES and GBI (hybrid grey-green infrastructure, land appropriation, environmental impacts, etc.; e.g., Grimm et al. 2016, Depietri and McPhearson 2017). Ostrom (e.g., 1999, 2009) showed how institutions frame the use of natural resources and not least the distribution of benefits, making them highly relevant for understanding use and its influence on the system (see also, e.g., Webster 2002, 2007, Colding and Barthel 2013). Finally, perceptions include both urban residents' appraisal (including value attribution, agency in the sense of recognition of opportunities offered by the combined GBI, infrastructure, and institutions) of and capacity (based on multiple individual factors such as age, preferences, socioeconomic circumstances, etc.) to use the system. We hold perception to be the basis for final realization of benefits (e.g., Pierskalla and Lee 1998, Chemero 2003, Spangenberg et al. 2014, Chan et al. 2016, Raymond et al. 2018). Perception also provides a more individual, actor-based perspective to balance the focus on more systemic properties and processes in the other two filters. All three are thus analytically relevant and, importantly, they all come with intervention tools (e.g., policy instruments) for changing the system.

If the overall effect of a filter or combination of filters is that it reduces the flow of benefits, it constitutes a barrier, e.g., insufficient funds among certain groups of potential visitors for paying entrance fees to an urban park (Wolff, Mascarenhas, Haase, et al., unpublishedmanuscript). If instead the filter supports or strengthens the flow of benefits, it forms an enabling factor. For example, extensive infrastructure for cycling and walking connecting parks to residential areas and business districts enables more people to visit and make use of the parks. Benefits differ in their nature and any of the three variables can manifest as an 
Fig. 1. The combination of three filters, infrastructure, institutions, and people's perceptions and capacities, frame and influence the flow of ecosystem service benefits from urban green and blue infrastructure to urban residents. The filters exist, and manifest differently, across scales and the filtering effect will depend on the nature of the benefits: ecosystem service benefits are quite diverse, which is also reflected in how they interact with the filters. Cities are under constant pressure by drivers from the outside (external), including financial interests and investments, immigration, demographic changes, climate change etc., as well as internal processes of change and system feedback loops (a). System change can affect the flow of benefits from green and blue infrastructure (GBI) either directly by changing GBI itself, e.g., by changing its extent, quality, or composition (b), or by changing the filters around GBI and thereby their effect on the flows of benefits (c). The overall filtering is a combined effect of all three filters, and by working actively with aligning filters in (b) and (c) offers flexible ways for ensuring that the flows of benefits are maintained.
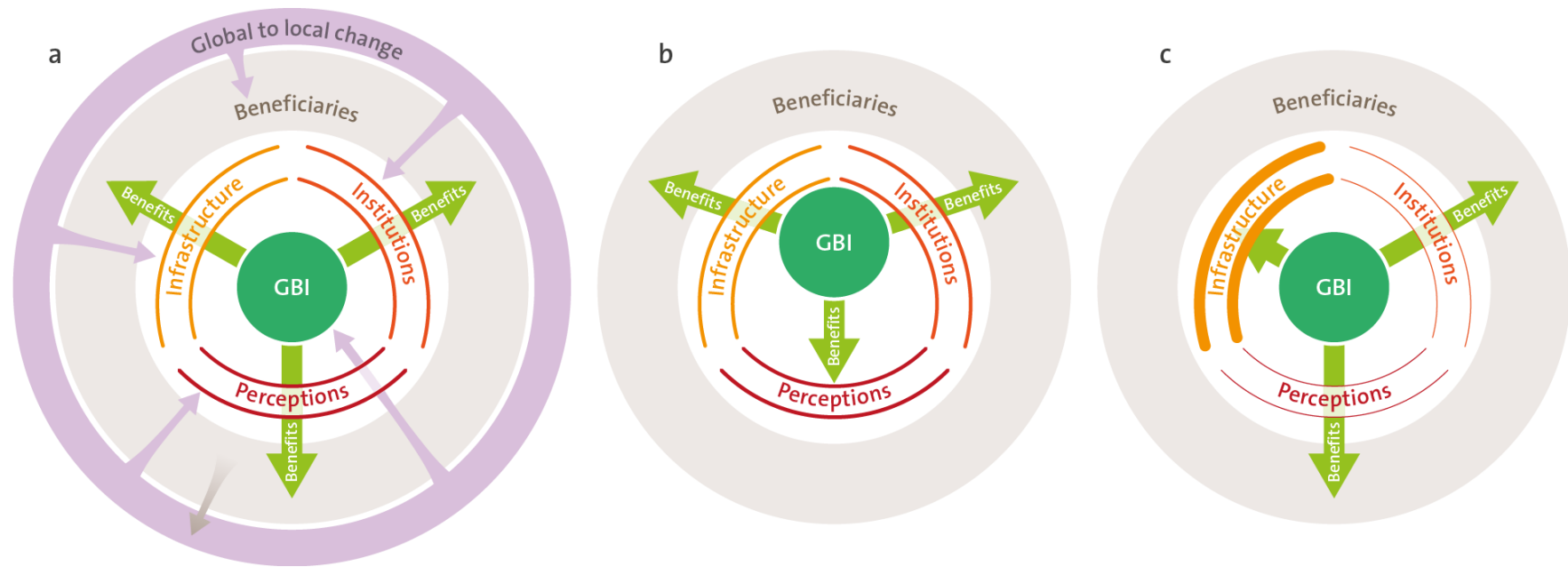

enabling factor for one benefit, while creating a barrier to others, meaning that the overall effect of a filter can be mixed (e.g., a fenced off-leash dog park). Different beneficiaries may also experience the effects differently, depending for example on socioeconomic circumstances or age.

Working with the flow of GBI benefits through the filters may thus include (1) revising or repurposing the structure or function of the urban infrastructure (e.g., introducing more green in densely built up areas, providing alternative transportation options for reaching different green or blue spaces, reducing space for private transportation/parking); (2) making changes in property rights and use regulations (e.g., changing ownership, introducing spatial or temporal zonation, adjusting regulations around use and mobility/transportation), and (3) engaging with perceptions (e.g., new narratives or processes that broaden, reframe, and challenge how we read and understand the city, which areas that can be used for what, by whom, how, and when; see, e.g., Marcus and Colding 2014).

The filters, like GBI itself, are exposed to external and internal drivers of change (e.g., Romice et al. 2018, Elmqvist et al. 2019), and a change in a filter is likely to have consequences for what benefits GBI can deliver and to whom these are accessible. Adapting to changes in the filters or actively changing them is essential for creating enabling contexts for realization of and distribution of GBI benefits (Fig. 1). We argue that the filters are fundamentally different in their dynamics and in which actors and processes can influence them in what ways. Hence, using the framework calls for flexible and adaptable mixed methods approaches that can tackle locally unique situations and decision making, differential access to information, and processes of deliberation (Andersson et al. 2021), as well as active involvement of multiple different actors that still allows for in-between case comparison (see Tables 1 and 2).

\section{APPLICATION: RESILIENCE THINKING AND THE THREE FILTERS IN PRACTICE}

In line with the growing literature on resilience in practice (and in applied research) we recognize the need for frameworks and methodological approaches that support analyses of the roots of resilience and potential pathways for building or, when needed, reducing resilience (Sellberg et al. 2018; Fig. 2). Building on practice developed around participatory resilience assessments, we explored how the three filters framework can guide in-depth understanding of ES co-production and pathways for building resilience around flows of GBI benefits. Our approach follows a three-step knowledge process for assessing and building resilience around the flow of benefits from GBI: baseline systems understanding, understanding systemic change in relation to internal and external drivers, and building agency and formulating action strategies (Borgström et al. 2021).

\section{Resilience in practice, research in action}

Different theories and analytical approaches have been applied to describe, assess, and engage in transdisciplinary collaborations aimed at producing actionable knowledge. They include coproduction or co-creation (e.g., Tengö et al. 2017, Norström et al. 2020, Turnhout et al. 2020, Cook et al. 2021), collaborative, inclusive, or participatory governance (e.g., Ansell and Gash 
Table 1. Three modes of transdisciplinary deliberation processes

\begin{tabular}{|c|c|c|c|c|}
\hline & Actors and engagement & Mandate and roles & Aims and scope & Case history \\
\hline Barcelona & $\begin{array}{l}\text { Researchers and strategic planners } \\
\text { (the City's Urban Resilience } \\
\text { Department) co-designing of } \\
\text { scenarios and deliberative process; } \\
\text { expert stakeholders (local NGOs, } \\
\text { private consultancies, small } \\
\text { enterprises, different levels and } \\
\text { departments of public } \\
\text { administrations, and academia) } \\
\text { joined later steps in the deliberative } \\
\text { process. }\end{array}$ & $\begin{array}{l}\text { The process was embedded in the } \\
\text { strategic planning of open space } \\
\text { resilience plan for the City of } \\
\text { Barcelona (the strategic planners } \\
\text { involved hold the mandate to } \\
\text { develop this plan). Aims and } \\
\text { targets, within the frames of the } \\
\text { planning process, were developed } \\
\text { jointly by the City of Barcelona } \\
\text { and the case researchers. }\end{array}$ & $\begin{array}{l}\text { To examine how the city's current } \\
\text { and future policies (may) enable } \\
\text { and hamper sustainable flows of a } \\
\text { priority set of ecosystem services } \\
\text { from green and blue infrastructure } \\
\text { (GBI), in the face of future needs } \\
\text { for ecosystem services driven by } \\
\text { external and internal change. } \\
\text { To identify policy solutions for } \\
\text { addressing a set issue. }\end{array}$ & $\begin{array}{l}\text { During the study, Barcelona City } \\
\text { Council was working on the } \\
\text { development of urban resilience } \\
\text { strategy (Ajuntament de Barcelona } \\
\text { 2018) through the coordinated work } \\
\text { of several city departments } \\
\text { including the recently established } \\
\text { City's Urban Resilience } \\
\text { Department. }\end{array}$ \\
\hline Halle & $\begin{array}{l}\text { Researchers, local civic } \\
\text { stakeholders (artists + } \\
\text { neighborhood association in } \\
\text { Freiimfelde and gardening/ } \\
\text { community initiative with } \\
\text { municipal budget in Neutopia), } \\
\text { partnership based on interest. } \\
\text { There was a "back up" process } \\
\text { involving city planners. }\end{array}$ & $\begin{array}{l}\text { Researchers owned the overall } \\
\text { iteration of the process at the } \\
\text { beginning but afterwards the } \\
\text { respondents/stakeholders "owned" } \\
\text { the interpretation and outcome } \\
\text { (supported by the researchers). }\end{array}$ & $\begin{array}{l}\text { To study the effects of regrowth, } \\
\text { after long-term shrinkage, on GBI } \\
\text { pattern, flows of benefits, } \\
\text { beneficiaries, and barriers. } \\
\text { To provide knowledge support for } \\
\text { changing perceived accessibility to } \\
\text { GBI benefits (residents) and } \\
\text { recommendations for how to } \\
\text { minimize barriers (city planning). }\end{array}$ & $\begin{array}{l}\text { Halle, in Central Germany, was at a } \\
\text { critical turning point from previous } \\
\text { population decline to re-growth } \\
\text { when the case study started. Halle } \\
\text { had been part of a larger peri- } \\
\text { urbanization study (PLUREL EU } \\
\text { project) as Twin-city of Leipzig } \\
\text { when first collaborations were } \\
\text { initiated. }\end{array}$ \\
\hline Stockholm & $\begin{array}{l}\text { Firmly based in long-term } \\
\text { interaction and trust-building with } \\
\text { a diversity of actors of the GBI in } \\
\text { the Stockholm region, the } \\
\text { researchers initiated and lead the } \\
\text { participatory, collaborative co- } \\
\text { production process where public, } \\
\text { private, and civic stakeholders were } \\
\text { included. }\end{array}$ & $\begin{array}{l}\text { The researchers initiated, framed, } \\
\text { designed, and facilitated the } \\
\text { process, whereas the other } \\
\text { stakeholders provided much of the } \\
\text { local knowledge that the process } \\
\text { was built around. All participants } \\
\text { jointly interpreted the outcomes } \\
\text { from different steps. }\end{array}$ & $\begin{array}{l}\text { To find, and build capacity for } \\
\text { finding, pathways for maintaining } \\
\text { multifunctionality across a nested } \\
\text { district level landscape with a } \\
\text { nature reserve in the middle of } \\
\text { ongoing urban densification. }\end{array}$ & $\begin{array}{l}\text { The study area was previously used } \\
\text { in a pilot study run by the } \\
\text { Stockholm municipality addressing } \\
\text { GBI as part of an urbanizing } \\
\text { landscape. The researchers were part } \\
\text { of that project and the participatory } \\
\text { process was partly designed as a } \\
\text { continuation. }\end{array}$ \\
\hline
\end{tabular}

2008, Buijs et al. 2016), and collaborative planning (e.g., Healey 1998, Sirianni 2007). We primarily drew on the work on coproduction to design our three cases, and took co-production to mean explicit involvement of individual citizens as well as organizational actors in the creation of (actionable) knowledge (more details on how we approached co-production can be found in Appendix 2). The application of the three filters framework was specific both to the case-three European cities, Halle, Barcelona, and Stockholm - and to each step in the process (Tables 1 and 2; see Andersson et al. 2021 for a more in-depth discussion of the flexible, multi-method designs) and presents an approach for context specific application in other cities.

In addition to the case specific objectives in terms of desired outcomes and which ES were in focus, guiding questions were (roughly in line with Resilience Alliance 2010, Enfors-Kautsky et al. 2018):

- Step 1: "How do the filters manifest in the case and what role they play for the flow of benefits?"; "In what ways are they enabling/hindering flows of benefits from GBI?"

- Step 2: "What are the main drivers of change in the filters and what are the expected consequences of change?"

- Step 3: "How can the filters be engaged with to build resilience around a desired future?"; "Who can do what?"

To capture these different aspects of filters and filtering, the three cases combined mixed methods designs weaving together deliberation with multiple other sources of information.

\section{Baseline}

The higher the capacity to mobilize and synthesize knowledge and then apply it to find alternative pathways for realizing and maintaining flows of GBI benefits, the more resilient the system (Biggs et al. 2015). Thus, understanding the system in a way that helps you explore and test different answers to your questions is the first step in a resilience assessment. The filters framing in this first step helped identify and connect relevant system components and processes (Table 1), and thus provided a broad basis for understanding diversity and connectivity, two of the core components of resilience building (Biggs et al. 2015).

The Barcelona baseline assessment focused on greening policies, a central institutional instrument, complemented by consultation and literature studies. The assessment of the system descriptions and potential sources of ES resilience (loosely connected to a set of prioritized ES, see Table 1) in the policy documents built on Biggs et al.'s seven principles for building resilience (Biggs et al. 2012) in combination with the resilience definition in Elmqvist et al. (2019) and the three filters framework from Andersson et al. (2019). More explicitly, infrastructure was framed as urban morphology, physical connectivity, and mobility, institutions as planning approaches, governance arrangements, mandates, and normative context, and perceptions as recognition of human preferences and lifestyles. Perceptions were also analyzed in terms of how linkages between these (and other) aspects were made in the policy documents (see De Luca et al. 2021). The baseline assessment also identified demographic change, increased visitation (tourism), and global warming as the three most likely and imminent changes that would affect the use of GBI benefits. 
Table 2. Overview, process, emphasis and outcomes of each case.

\begin{tabular}{ll}
\hline \hline Barcelona & Green and blue infrastructure (GBI) \\
& and a subset of prioritized benefits as \\
defined and described in policy & documents and prioritized by \\
& stakeholders. Infrastructure was framed \\
& as urban morphology, physical \\
& connectivity, and mobility, institutions \\
& as planning approaches, governance \\
& arrangements, mandates, and normative \\
& context, and perceptions as recognition \\
& of human preferences and lifestyles. \\
& Perceptions were also analyzed in terms \\
& of how linkages between these (and \\
& other) aspects were made in the policy \\
documents. & \\
GBI network and changes according to & the Halle Master Plan and other policy \\
documents combined with visions from \\
stakeholder interviews and results of \\
local meetings/discussions. Based on the \\
different sources of information a list \\
and a map of infrastructural (such as \\
major roads or distance, fences), \\
institutional (e.g., entrance fees or lack \\
of sectoral collaboration and \\
information exchange), and perceptual \\
(e.g., negative images, user/beneficiary \\
knowledge, and individual preferences) \\
barriers were created.
\end{tabular}

Stockholm Different perceptions of opportunities and constraints as well as the overall attractivity of different recreational activities and the institutional context (e.g., previous and ongoing governance processes, and the scope and ambit of different policy spheres/sectors) were compiled through researcher expertise and key informant consultation together with stakeholder mapping and a scoping review of policy documents. Infrastructure was assessed in terms of user mobility and the spatial configuration and connectedness of different activity-specific preconditions.
Understanding change

Drivers of change were assessed and evaluated through co-designed scenarios of ecosystem services

(ES) supply and demand in alternative futures: (1) an aging and shrinking population (with a strong infrastructure/mobility component), (2) increasing tourist visitation (addressing, among other things, institutional design), (3) gender inequalities (including perceptions), and (4) global warming. The drivers combined external factors with internal changes in the three filters.

A forecasting model was used to calculate the growth of residential space (infrastructure) and demand and use of GBI (perceptions and

to some extent institutions). Policy targets, plans, and strategies were treated as institutional drivers of change. The model development was primed and evaluated through interviews with experts regarding expected developments and uncertainties (infrastructure and institutions), and local stakeholders (exploring perceptions of physical accessibility).

Two sets of narrative scenarios were created based on different combinations and expression of four filter mediated drivers of change: (1) urban development (changes in infrastructure), (2) environmental and climate change, (3) forms of housing tenure (institutions and indirectly perceptions), and (4) governance organization and decision making (institutions). The scenarios were described, discussed, and evaluate in terms of their implications for recreational activities. Direct and indirect changes were inferred from the effect the scenarios were expected to have on different filter preconditions.
Building agency and formulating strategies

Infrastructure: Need for further integration of grey and green infrastructure in the city. Need to consider global teleconnections of ES consumption and production in cities discussed in the context of touristic infrastructure.

Institutions: Need for inter-sectoral integration of policies and collaboration, including greening, mobility, tourism, health, education.

Perceptions: Need to tackle (feeling of) insecurity and the unjust distribution of ES benefits from a gender and age perspective; support value creation and recognition of urban GI.

Infrastructure: Need for better integration of high quality GBI across the city including multi-functionality, the satisfaction of different recreation demands, and safety. Better connectivity between the high value nature parts of the Halle GBI: wetlands, hills, and abandoned vineyards.

Institutions: Detailed plans and local activities in districts and neighborhoods need to be better connected to strategic GBI planning.

Perceptions: Better recognition of general neglect of urban districts in the local discourse and urban policies. Dignity of residents of all districts as an entry point for participation. Negative neighborhood stereotypes cause local GBI benefits to be underutilized.

Infrastructure: Need to ensure that preconditions are distributed more evenly across the landscape to improve and extend recreational opportunities. Alignment of green and grey is key for connecting the landscape and enabling activities with more extensive spatial scales.

Institutions: Strong landowner rights, sectoral and administrative boundaries were seen as two of the main barriers to alternative ways for engaging with the urban landscape and the flow of GBI benefits. Strong formal institutions together with somewhat rigid perceived roles and self-identities (professional and otherwise) constrain multilevel and cross-sector resilience thinking.

Perceptions: Need to reduce governance opacity and facilitate in-depth understanding of bottom-up pathways for influencing governance processes. Need to extend the change narrative from external, abstract threats, to also include internal system dynamic that can have both positive and negative outcomes.
Focusing on filters as barriers to access to and general recreational use of different green spaces, Halle took a spatially explicit approach to establishing the baseline system representation. The baseline was informed by existing ES model outcomes (Arnold et al. 2018, Gorn et al. 2018), interviews, and in-situ assessment of use and land use patterns. Most of the interviews were conducted through mental mapping survey (perceptions) about use or non-use of GBI (Haase et al. 2021), complemented by a wider literature-based exploration of reasons for not using GBI, including also infrastructural (physical) and institutional constraints to accessing GBI benefits. Based on this information a list and a geographical map of infrastructural (such as major roads or distance, fences), institutional (e.g., entrance fees or lack of sectoral collaboration and information exchange), and perceptual (e.g., negative images, user/beneficiary knowledge, and individual preferences) barriers were created (Barber et al. 2021, Wolff 2021; Wolff, Mascarenhas, Haase, et al., unpublished manuscript). Thus, in addition to the more direct barriers, the baseline study highlighted less recognized barriers like stigma and place identities or images (perceptions) as underlying drivers that shape GBI access and use. 
Fig. 2. Outline of the stepwise iterative system exploration and knowledge building.

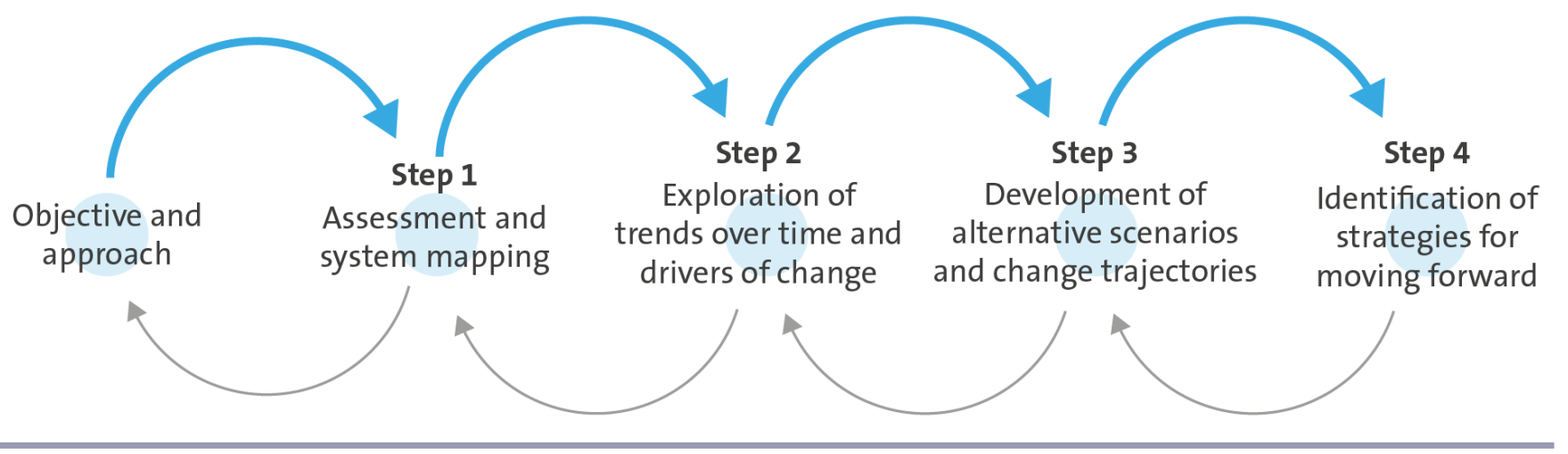

The Stockholm case had the most in-depth approach to ES, unpacking the filter settings-preconditions - necessary for different recreational ES. In a first focus group interview, benefits from GBI were discussed as nature-based outdoor recreation activities and described in terms of the different preconditions (different aspects of the filters, mostly) necessary for engaging in the activities (Borgström, Andersson, and Björklund, unpublished manuscript). Different perceptions of opportunities and constraints as well as the overall attractiveness (understood through the preconditions) of different recreational activities and the institutional context (land use, stakeholders, and previous and ongoing governance processes, and the scope and ambit of different policy spheres/sectors) were compiled through researcher expertise and key informant consultation together with stakeholder mapping and a scoping review of policy documents (see Borgström et al. 2021). Finally, infrastructure was assessed in terms of user mobility and the spatial configuration and connectedness of different preconditions (specific to each recreational activity).

\section{Understanding change}

To understand the role of filters as conduits/drivers of change and/or evaluative tools for connecting change to ES and benefit flows we argue that you need to include two different perspectives: external drivers of change and how they affect the filters and thus indirectly the flow of GBI benefits, and how the filters interact and influence each other. Involving diverse stakeholders in different scenario and modeling exercises offers opportunities to explore both alternative options and possibilities within a given filter setting and potential interventions or actions for changing the context itself (e.g., Pereira et al. 2019, Sellberg et al. 2020). Focusing on awareness and understanding of filters as slow variables and boundary conditions (sensu Biggs et al. 2015) and their role for co-created GBI benefits, Stockholm and Barcelona used researcher-led, collaborative co-creation approaches to scenarios for thoroughly discussing the implications of different types of more systemic changes. Complementing these, the Halle computational modeling approach to scenarios was more spatially explicit and primarily expert driven, focusing on land use change and modeling the outcomes of different change scenarios on GBI benefits (expressed in ES performance).

In Barcelona, the scenario approach was co-designed by the researchers and city level strategic planners while the scenario workshop itself involved a wider group of expert stakeholders (local NGOs, private consultancies, small enterprises, different levels and departments of public administrations, and academia). Scenarios were first used to assess and envisage changes in GBI capacity (infrastructure) and demand (perceptions) in terms of a set of prioritized ES. Four different trajectories of change were explored in parallel, each focusing on one of the identified drivers of change: (1) aging and shrinking population (with a strong infrastructure/mobility component), (2) increased tourism (with institutional implications), (3) gender inequalities (emphasizing perceptions), and (4) global warming. For each future scenario, participants were asked to assess potential changes in ES based on combination of the following factors: (1) increase/decrease in the number of users and relative awareness of benefits leading to higher/lower pressure on urban GBI, shift in ecosystem service demand; (2) increase/decrease in availability of urban GBI leading to lower/higher ecosystem service capacity.

Halle used a land use state/trend-based forecast modeling approach for developing spatially explicit scenarios, based on existing previous knowledge (Nilsson et al. 2014) and core competence of the researcher's team. The model included expected demand for residential space (infrastructure), use of GBI and a range of benefits derived from GBI (perceptions and to some extent institutions). Policy targets, plans, and strategies were treated as institutional drivers of change (e.g., policy changes), including to the extent of the participants' knowledge potential changes in user rights (e.g., privatization). The model development was informed by consulting the Urban Planning department (interviews with experts regarding expected developments and uncertainties [infrastructure and institutions], used to create or modify rules for the land use model) and local neighborhood initiatives and perspectives (through the baseline mental mapping study exploring physical accessibility and how this might be perceived by different users, Haase et al. 2021). The model focused on infrastructural and land use change as predicted by land use configuration and external drivers. The scenarios generated by the model used filters as the medium connecting more generic drivers of change to their implications for the access to GBI benefits. However, the scenarios were at the city scale of Halle, and at this coarse scale there was not enough information to include in-depth dynamics based on individual (residents) perceptions. 
Based on the baseline information, the Stockholm research team selected four key drivers acting directly or indirectly through the three filters: (1) urban development (changes in infrastructure), (2) environmental and climate change, (3) forms of housing tenure (institutions and indirectly perceptions), and (4) governance organization and decision making (institutions). These served as the foundation for a facilitated participatory workshop designed to explore and build a joint understanding of what was changing in landscape and how the drivers of change interact and potentially shape the future provision of recreational benefits (Borgström et al. 2021). Substantial time was invested in adjusting and modifying the filters framing the process and its targets to accommodate for varying familiarity with systems thinking as well as establishing a language for connecting perceptions. The scenarios were described and evaluated in terms of changes in preconditions (including elements from all three filters) and their implications for nature-based recreational activities.

\section{Building agency and formulating strategies}

All three cases came to focus on slow changes and how to navigate long-term transitions, which may be a result of limited experiences with recent shocks or abrupt change (Borgström et al. 2021). The last step of the process focused on enabling factors that support current (or could support future) use of different ES afforded by GBI. To meet an overall increased demand for an uncertain supply of GBI benefits, the actions and measures discussed fall into two broad categories: (1) interventions aimed at increasing and sustaining current GBI infrastructures and measures that would improve access to GBI benefits for urban residents; and (2) alternative ways to make decision making and overall governance more resilient by involving stakeholders in different ways and better mobilize knowledge and resources.

Having the most specific objective and best fit between involved stakeholder mandates and the targeted decision making/policy formulation, Barcelona was the case that came closest to directly informing decisions. When asked to develop policy adaptations based on the identified shifts in provision and demand for different ES, workshop participants often proposed infrastructural and institutional measures connecting to policy sectors such as mobility, tourism, and health. Although the impact of ES on human health and well-being are at the center of many studies, identified measures in Barcelona also captured the need to better monitor long-term health benefits and the capacity of GBI to fulfil this need. The discussions triggered by the scenarios identified institutional connectors for integrating urban greening and planning with health, tourism, transport and mobility, education, and awareness. Although it is broadly recognized that urban planning decisions in sectors such as land use (e.g., Jennings et al. 2012, Hansen et al. 2015), transport and mobility (e.g., Cidell and Prytherch 2015), and tourism (e.g., Taff et al. 2019) have a strong impact on the GBI capacity to provide ES over time, the Barcelona case suggested that these changes also have an effect on ecosystem service demand, as they implicitly affect perceptions. However, workshop participants had few suggestions for how to engage with perceptions, possibly because this falls outside the usual ambit of strategic planning (De Luca et al. 2021).

In the Halle case, the outcomes of the study were twofold: First, the quantitative scenario outcomes provided input for a multifaceted discussion of how urban re-growth (primarily infrastructure) can be accomplished in a way that ensures the availability of GBI benefits at the district level. Second, the case highlighted how the identification of strategies for changing the current situation of GBI non-use at local scale, which is included in the city wide scenarios but not explicitly addressed, was hampered by perceived disempowerment and actors not seeing how they could make change happen. Here, scenario outcomes, while informative for science, appeared to be too coarse or general to support design or management decisions. Institutionally, there seems to be a gap between having power and mandate to influence infrastructure and formal institutions and the sensibility to recognize local perceptions and take specific action, a problem shared with the other two cases.

In the Stockholm case the final steps of the process concerned options for taking action based on a broadened understanding of the system, where the majority of the suggestions was about adaptations of present institutions, e.g., actors taking new roles, establishing collaborations and new rules, and securing capacity for continued dialogue across levels, sectors, and actors. The discussion lifted issues of how to use and connect existing, but fragmented knowledge, rather than monitoring or collecting additional information. Perceived lack of knowledge or agency (understood especially as limited access to decisions about infrastructure and institutions), possibly in combination with the Stockholm focus on capacity building rather than specific, bounded problems, kept discussions and strategies rather general. The discussions centered on governance and the different institutional processes and tools that could influence each, e.g., by urban planning as a decision-making process, institutions by new policies framing use or planning, or change in policy implementation, and peoples' experienced benefits being the key target for the governance rather than specific actions or how these could be achieved.

Insights and implications and areas in need of further exploration One of the main challenges of complex systems and actively building or reducing specific resilience is to assess, catalogue, and connect diversity. The three filters framework can help actors identify and harness diversity, across SETS domains, by finding the linkages (thematic, policy, structures, actors, etc.) for connecting and aligning diversity relevant for different ES (as well as other "systemic" features). As the Barcelona and Stockholm cases show, a filter framed joint knowledge process for understanding the different preconditions and potential sources of GBI resilience can inform both potential solutions and clearly identify cases of, e.g., policy fragmentation or sectoral siloes. Our cases point to the need to understand connectivity also in less literal senses; beyond infrastructure there are institutional and perceptual linkages that are quite important for connecting different parts of a SETS, and taking action based on this understanding. A systems-based approach framed by the three filters offers both a foundation for developing and evaluating future scenarios and access to a broad suite of intervention options; especially infrastructure and institutions are two of the primary fields in policy and planning (Frantzeskaki et al. 2019, Pauleit et al. 2019). Understanding how the filters respond to internal and external stimuli and the implications of these ofteninteracting responses on ES generation and flows of benefits can help urban proactive planning and reflecting on long-term 
Table 3. Emergent key issues (within and across filters) for building resilience around flows of green and blue infrastructure (GBI) benefits applying a social-ecological-technological systems (SETS) perspective including human perceptions, institutions, and infrastructure contexts affecting GBI.

\begin{tabular}{|c|c|c|c|}
\hline & Perceptions & Institutions & Infrastructure \\
\hline Infrastructure & $\begin{array}{l}\text { Flexible distance thresholds, preferences } \\
\text { for different modes of transportation, } \\
\text { opportunities for making transportation } \\
\text { part of the experience, flexibility in terms } \\
\text { of functional scale, active mediation and } \\
\text { facilitation for specific groups and needs } \\
\text { including conflicts/conflicting views. } \\
\text { Accessible navigation tools and } \\
\text { information. }\end{array}$ & $\begin{array}{l}\text { Diverse regulatory options concerning } \\
\text { when and where different infrastructures } \\
\text { can be used, benefits/functional linkages } \\
\text { as boundary objects for policy } \\
\text { consistency and streamlining. }\end{array}$ & $\begin{array}{l}\text { Redundant routes, diverse transportation } \\
\text { options/repurposing of existing built } \\
\text { infrastructure, relatively fine-grained grey- } \\
\text { green integration/interspersion (redundant } \\
\text { land use pairings and new combinations). }\end{array}$ \\
\hline Institutions & $\begin{array}{l}\text { Perceived agency, easily legible multiple } \\
\text { opportunities/alternatives for being } \\
\text { involved in decision making or joint } \\
\text { learning activities. More flexible informal } \\
\text { interpretations and praxis around formal } \\
\text { institutions. }\end{array}$ & $\begin{array}{l}\text { Polymorph coalitions with flexible roles, } \\
\text { capacity for collective action, dynamic } \\
\text { land use designations, continuity in } \\
\text { venues for joint deliberation and decision } \\
\text { making. Mandates that transcend sectoral } \\
\text { divisions and prevailing power } \\
\text { asymmetries. }\end{array}$ & \\
\hline Perceptions & $\begin{array}{l}\text { Landscape literacy and user knowledge, } \\
\text { accessibility of information. Flexibility in } \\
\text { terms of under which circumstances an } \\
\text { activity would be "attractive." }\end{array}$ & & \\
\hline
\end{tabular}

strategies; connecting different sources of diversity in new ways can open up opportunities to come up with alternative ways to do things (Buijs et al. 2016, Elmqvist et al. 2018b). Finally, the filters provide a language, or comparators (sensu Jacobs 2012), for joint learning, system exploration, and connecting visions and practices, within and between cases. Deliberations and joint exploration in Stockholm and Barcelona were especially helped by the filters as boundary or bridging concepts connected across interests, processes, and spheres. In Stockholm, recreational activities and their preconditions (e.g., user rights, facilities, knowledge, and capacities) served as a meaningful reference frame for the participants, whereas in Barcelona the use of broadly agreed on drivers of change helped connect the resilience thinking process to existing concepts and frameworks. Halle instead used infrastructure modeling as the starting point for comprehensively linking drivers of change with GBI-generated flows of benefits to beneficiaries to better be able to provide meaningful and accessible material for planned participatory processes integrated in the realization of the Master Plan of the town.

Existing governance processes and arrangements may be inadequate for navigating transformative change, or when interactive effects of filters undergoing change start to affect the flow of GBI benefits (Borgström 2019). Thus, even when filter settings are enabling flows of GBI benefits one might be interested in alternatives that better fit multiple ambitions and targets (Table 3). In the Stockholm case, for example, using and slightly repurposing stronger institutional instruments (e.g., designating areas to different types of formal protection, mainstreaming ES) is an active strategy for safeguarding at least core elements of the GBI. Beyond these basic principles, the actual factors to include will need to be decided by the case (see De Luca et al. 2021). One of the advantages of applying the three filters framework in different deliberative joint learning processes dedicated to understanding how the system works and anticipating future change is that it actively engages with perceptions and understandings of the stakeholders involved. This engagement helps strengthen the capacity to understand and use the current system in different or alternative ways, and to build the agency needed to get involved with changing infrastructures and institutions (e.g., Colding and Barthel 2013, Sellberg et al. 2018). This approach also offers an entry point for in-depth engagement with equity and justice issues (Langemeyer and Connolly 2020). According to the participants' evaluations (Stockholm), an added benefit (and important contribution to the capacity to engage in resilience building along with the systems understanding) was the opportunity to make new contacts, and the process was found to fill an experienced lack of platforms for such system wide exchanges. The conclusion from our cases is that the joint learning started through a resilience thinking process must move back and forth between specific aspects of the filters and the broader systems understanding of how the filters fit together and how they jointly influence the flows of GBI benefits.

Our study shows that perceptions, as inherent parts of the system as well as a key actor attribute, need to be more explicitly woven into urban resilience work. Our studies clearly show the transformative and potentially enabling power of perceptions. Perceptions of, for example, the attractiveness of GBI elements are often quite volatile - in Barcelona a few crime events shifted the accessibility/safety perceptions of one of the largest urban parks within weeks. On the other hand, overall understanding of the system and how you can engage with it both as a user and a decision maker/manager is a slower process, and one that needs to be continuously nurtured (in the sense of weaving types of knowledge, Tengö et al. 2017). Yet, the readiness to anticipate change in and engage with the filters follows the opposite pattern. For infrastructure and institutions, it is relatively clear what is required/should be done to implement changes, and who could implement the changes. For perceptions, this seems to be much more complex or at least fuzzy. 


\section{Process constraints}

In all cases, especially Barcelona and Stockholm, the stakeholders found it difficult to imagine "business as (un)usual" futures and to think outside their boxes of everyday practice and imagine potential radical future changes. The perceptions of the respective cities were in many ways quite static, especially concerning the built components and the institutions. At a fundamental level, the cases point to the need to think more about preparing also for more unlikely futures and discuss the interactions of multiple drivers of change. Similar to what other studies have shown (e.g., Borgström et al. 2006, Cumming et al. 2015), our cases also demonstrated the combined challenge of cross scale interactions and sectoral fragmentation when interventions normally take the form of interdependent tasks (as described by, e.g., Bodin and Nohrstedt 2016). Objectives that may seem closely connected from a scientific perspective may require very different processes (and actors) to be implemented (for an in-depth discussion about the participatory co-creation processes see De Luca et al. 2021 and Borgström et al. 2021).

Strong path dependency or resilience of enabling factors for flows of GBI benefits would, from the perspective of this study, be something positive. However, because the filters may also function as barriers, filter resilience can be an undesirable feature. Undesirable resilience, often called lock-in or a trap, can be understood as cases when filters, acting as barriers, resist desired change or constrain the range of alternative configurations (e.g., Walker 2000, Boonstra and De Boer 2014, Tidball et al. 2016). In Stockholm, for example, formal institutions, especially around urban planning, were perceived as quite limiting (and hard to change) in what they allow and what kind of involvement in planning processes they support (Borgström et al. 2021). In an extended discussion about system inertia, Stedman (2016) contended that constructs such as system identity, stability and changes, are subjectively perceived, and acted upon by the social actors that occupy these systems, but that the lack of recognition of this subjectivity has itself become a "rigidity trap." In Halle, persistent negative perceptions and the existence of other, more attractive options for accessing GBI benefits at larger but still manageable scales, were identified as one of the main barriers to why local GBI potential was not realized within residents' own neighborhoods. This negative impression, or sometimes just unrecognized opportunity, we believe is partly connected to a feeling of marginalization and not being part of decision making. The experience from Halle was that lacking capacity and trust, together with very specific and therefore limited interest, across scales and sectors, obstructed both the development of a shared problem understanding and the identification of actionable strategies for addressing the problems.

Perceived or real, the literature on institutional traps describes them as created and reinforced by mechanisms of optimization, set identities and communities of practice and learning, and cultural inertia (e.g., Azariadis and Stachurski 2005). In terms of the learning process itself, rather than its outcomes, our three cases demonstrated institutional (and perhaps perceptual) constraints to what could be accepted as a legitimate process design. Our interpretation is that this was based on an institutional memory of (1) how decision making and deliberate processes are usually organized and how targets (relevant to our processes) are framed (governance traditions in each city), and (2) participant experiences of earlier co-creation or collaborative processes. As a consequence, we experienced some restrictions as to how we could discuss resilience, which strategies and solutions they were interested in exploring, and which of these that might actually be feasible without larger transformations of the system.

\section{IN CONCLUSION}

Cities, with their deep embodiment of human ideas and activities, highlight some of the fundamental aspects of the Anthropocene where human impacts are felt in every corner of the world. The three filters framework describing cities in terms of physical infrastructure, societal institutions, and human perceptions and capacities is a powerful tool for understanding and engaging with urban SETS. It is also a starting point for directly engaging with perceptions. However, although universally applicable in general terms, the three filters framework needs to be adapted and fitted to local contexts and case specific needs. The three step learning process described in this article (Fig. 2) - system mapping, system dynamics, alternative futures and finding resilient strategies for change - offer a pathway for tackling urban complexity and operationalizing resilience thinking for building capacity and agency needed to take action. It is a process that enables stakeholders to widen their perspective of the GBI including more different activities, being part of a changing landscape, and also reflecting on their present and potential role as individual and collective stakeholders in that landscape.

To achieve this, approaches that employ resilience thinking need to keep adjusting to both local normative goals, as well as the broader dynamics of the SETS that constrains or enables progress to achieve them. Our cases show how the filters framework can guide joint learning processes, and how specific meanings and interpretations of the filters and their effects evolve with the learning process. The three cases show, first, how the filters framework can be used to assess current flows of different GBI benefits and map out different SETS characteristics and contextsensitive configurations that may offer alternative ways of enabling benefit flows. Second, with their central role in mediating flows of benefits from GBI, the filters provide a key component for scenario or model building. Finally, focusing on the filters and their interactions serves as an entry point for discussing how different actors can contribute to making flows of benefits more resilient. To make the action strategies realistic a deep understanding of the filters themselves, their dynamics, resilience, and potential levers, is essential, and that all actors with influence over the three filters share this understanding. Although the primary focus of this paper was the resilience of flows of GBI benefits, our results point to the need for future studies to position this specific resilience as embedded in the resilience or changeability of the three filters.

Responses to this article can be read online at: https://www.ecologyandsociety.org/issues/responses. php/12691

\section{Acknowledgments:}

This research was funded through the 2015-2016 BiodivERsA COFUND call for research proposals, with the national funders the 
Swedish Research Council for Environment, Agricultural Sciences, and Spatial Planning; the Swedish Environmental Protection Agency; the German Aerospace Center; the National Science Centre (Poland; grant no. 2016/22/Z/NZ8/00003); the Research Council of Norway; and the Spanish Ministry of Economy and Competitiveness. EA's and SB's participation was additionally supported by Formas project number 2015-00734. SB's participation was additionally supported by the School of Architecture and Built Environment at the Royal Institute of Technology, in Stockholm, Sweden. JL acknowledges support from the ERC Consolidator Grant 818002-URBAG. TM's participation was additionally supported by the U.S. National Science Foundation through grants \#1444755, \#1927167, and \#1934933.

\section{LITERATURE CITED}

Andersson, E., S. Borgström, D. Haase, J. Langemeyer, A. Mascarenhas, T. McPhearson, M. Wolff, E. Łaszkiewicz, J. Kronenberg, D. N. Barton, and P. Herreros-Cantis. 2021. A context-sensitive systems approach for understanding and enabling ecosystem service realization in cities. Ecology and Society 26(2):35. https://doi.org/10.5751/ES-12411-260235

Andersson, E., J. Langemeyer, S. Borgström, T. McPhearson, D. Haase, J. Kronenberg, D. N. Barton, M. Davis, S. Naumann, L. Röschel, and F. Baró. 2019. Enabling green and blue infrastructure to improve contributions to human well-being and equity in urban systems. BioScience 69(7):566-574. https://doi. org/10.1093/biosci/biz058

Andersson, E., T. McPhearson, P. Kremer, E. Gomez-Baggethun, D. Haase, M. Tuvendal, and D. Wurster. 2015. Scale and context dependence of ecosystem service providing units. Ecosystem Services 12:157-164. https://doi.org/10.1016/j.ecoser.2014.08.001

Ansell, C., and A. Gash. 2008. Collaborative governance in theory and practice. Journal of Public Administration Research and Theory 18(4):543-571. https://doi.org/10.1093/jopart/mum032

Arnold, J., J. Kleemann, and C. Fürst. 2018. A differentiated spatial assessment of urban ecosystem services based on land use data in Halle, Germany. Land 7(3):101. https://doi.org/10.3390/ land 7030101

Azariadis, C., and J. Stachurski. 2005. Poverty traps. Pages 295-384 in P. Aghion and S. N. Durlauf, editors. Handbook of economic growth. Elsevier, Amsterdam, The Netherlands. https:// doi.org/10.1016/S1574-0684(05)01005-1

Barber, A., D. Haase, and M. Wolff. 2021. Permeability of the city - physical barriers of and in urban green spaces in the city of Halle, Germany. Ecological Indicators 125:107555. https://doi. org/10.1016/j.ecolind.2021.107555

Biggs, R., M. Schlüter, D. Biggs, E. L. Bohensky, S. BurnSilver, G. Cundill, V. Dakos, T. M. Daw, L. S. Evans, K. Kotschy, A. M. Leitch, C. Meek, A. Quinlan, C. Raudsepp-Hearne, M. D. Robards, M. L. Schoon, L. Schultz, and P. C. West. 2012. Toward principles for enhancing the resilience of ecosystem services. Annual Review of Environment and Resources 37(1):421-448. https://doi.org/10.1146/annurev-environ-051211-123836

Biggs, R., M. Schlüter, and M. L. Schoon, editors. 2015. Principles for building resilience: sustaining ecosystem services in social- ecological systems. Cambridge University Press, Cambridge, UK. https://doi.org/10.1017/CBO9781316014240

Bodin, Ö., and D. Nohrstedt. 2016. Formation and performance of collaborative disaster management networks: evidence from a Swedish wildfire response. Global Environmental Change 41:183-194. https://doi.org/10.1016/j.gloenvcha.2016.10.004

Boonstra, W. J., and F. W. De Boer. 2014. The historical dynamics of social-ecological traps. Ambio 43(3):260-274. https://doi. org/10.1007/s13280-013-0419-1

Borgström, S. 2019. Balancing diversity and connectivity in multilevel governance settings for urban transformative capacity. Ambio 48(5):463-477. https://doi.org/10.1007/s13280-018-01142-1

Borgström, S., E. Andersson, and T. Björklund. 2021. Retaining multi-functionality in a rapidly changing urban landscape: insights from a participatory, resilience thinking process in Stockholm, Sweden. Ecology and Society 26(4):17. https://doi. org/10.5751/ES-12432-260417

Borgström, S. T., T. Elmqvist, P. Angelstam, and C. AlfsenNorodom. 2006. Scale mismatches in management of urban landscapes. Ecology and Society 11(2):16. https://doi. org/10.5751/ES-01819-110216

Buijs, A., T. J. Mattijssen, A. P. Van der Jagt, B. Ambrose-Oji, E. Andersson, B. H. M. Elands, and M. Steen Møller. 2016. Active citizenship for urban green infrastructure: fostering the diversity and dynamics of citizen contributions through mosaic governance. Current Opinion in Environmental Sustainability 22:1-6. https://doi.org/10.1016/j.cosust.2017.01.002

Chan, K. M. A., P. Balvanera, K. Benessaiah, M. Chapman, S. Díaz, E. Gómez-Baggethun, R. Gould, N. Hannahs, K. Jax, S. Klain, G. W. Luck, B. Martín-López, B. Muraca, B. Norton, K. Ott, U. Pascual, T. Satterfield, M. Tadaki, J. Taggart, and N. Turner. 2016. Opinion: Why protect nature? Rethinking values and the environment. Proceedings of the National Academy of Sciences 113(6):1462-1465. https://doi.org/10.1073/pnas.1525002113

Chemero, A. 2003. An outline of a theory of affordances. Ecological Psychology 15(2):181-195. https://doi.org/10.1207/ $\underline{\text { S15326969ECO1502 } 5}$

Cidell, J., and D. Prytherch. 2015. Transport, mobility, and the production of urban space. Routledge, New York, New York, USA. https://doi.org/10.4324/9781315709680

Colding, J., and S. Barthel. 2013. The potential of 'urban green commons' in the resilience building of cities. Ecological Economics 86:156-166. https://doi.org/10.1016/i.ecolecon.2012.10.016

Cook, E. M., M. Berbés-Blázquez, L. M. Mannetti, N. B. Grimm, D. M. Iwaniec, and T. Muñoz-Erickson. 2021. Setting the stage for co-production. Page 99-112 in Z. Hamstead, D. Iwaniec, T. McPhearson, M. Berbés-Blázquez, E. M. Cook, and T. A. Muñoz-Erickson, editors. Resilient urban futures. Springer, Cham, Switzerland. https://doi.org/10.1007/978-3-030-63131-4_7

Cumming, G. S., C. R. Allen, N. C. Ban, D. Biggs, H. C. Biggs, D. H. M. Cumming, A. De Vos, G. Epstein, M. Etienne, K. Maciejewski, R. Mathevet, C. Moore, M. Nenadovic, and M. Schoon. 2015. Understanding protected area resilience: a multi- 
scale, social-ecological approach. Ecological Applications 25 (2):299-319. https://doi.org/10.1890/13-2113.1

De Luca, C., J. Langemeyer, S. Vaňo, F. Baró, and E. Andersson. 2021. Adaptive resilience of and through urban ecosystem services: a transdisciplinary approach to sustainability in Barcelona. Ecology and Society 26(4):38. https://doi.org/10.5751/ ES-12535-260438

Depietri, Y., and T. McPhearson. 2017. Integrating the grey, green, and blue in cities: nature-based solutions for climate change adaptation and risk reduction. Pages 91-109 in N. Kabisch, H. Korn, J. Stadler, and A. Bonn, editors. Nature-based solutions to climate change adaptation in urban areas: linkages between science, policy and practice. Springer, Cham, Switzerland. https:// doi.org/10.1007/978-3-319-56091-5 6

Edwards, M. G. 2020. Mapping resilience theory: a metatheoretical exploration. Pages 13-42 in M. Endress, L. Clemens, and B. Rampp, editors. Strategies, dispositions and resources of social resilience: a dialogue between medieval studies and sociology. Springer VS, Wiesbaden, Germany. https://doi. org/10.1007/978-3-658-29059-7 2

Elmqvist, T., E. Andersson, N. Frantzeskaki, T. McPhearson, P. Olsson, O. Gaffney, K. Takeuchi, and C. Folke. 2019. Sustainability and resilience for transformation in the urban century. Nature Sustainability 2:267-273. https://doi.org/10.1038/ $\underline{\text { s41893-019-0250-1 }}$

Elmqvist, T., E. Andersson, T. McPhearson, X. Bai, L. Bettencourt, E. Brondizio, J. Colding, G. Daily, C. Folke, N. Grimm, D. Haase, D. Ospina, S. Parnell, S. Polasky, K. Seto, and S. Van der Leeuw. 2021. Urbanization in and for the Anthropocene. npj Urban Sustainability 1:6. https://doi. org/10.1038/s42949-021-00018-W

Elmqvist, T., X. Bai, N. Frantzeskaki, C. Griffith, D. Maddox, T. McPhearson, S. Parnell, P. Romero-Lankao, D. Simon, and M. Watkins, editors. 2018a. Urban planet. Cambridge University Press, Cambridge, UK. https://doi.org/10.1017/9781316647554

Elmqvist, T., J. Siri, E. Andersson, P. Anderson, X. Bai, P. K. Das, T. Gatere, A. Gonzalez, J. Goodness, S. N. Handel, E. Hermansson Török, J. Kavonic, J. Kronenberg, E. Lindgren, D. Maddox, R. Maher, C. Mbow, T. McPhearson, J. Mulligan, G. Nordenson, M. Spires, U. Stenkula, K. Takeuchi, and C. Vogel. 2018b. Urban tinkering. Sustainability Science 13:1549-1564. https://doi.org/10.1007/s11625-018-0611-0

Enfors-Kautsky, E., L. Järnberg, A. Quinlan, and P. Ryan. 2018. Wayfinder: a resilience guide for navigating towards sustainable futures. [online] URL: https://wayfinder.earth/

Ernstson, H. 2013. The social production of ecosystem services: a framework for studying environmental justice and ecological complexity in urban landscapes. Landscape and Urban Planning 109:7-17. https://doi.org/10.1016/j.landurbplan.2012.10.005

Frantzeskaki, N., T. McPhearson, M. J. Collier, D. Kendal, H. Bulkeley, A. Dumitru, C. Walsh, K. Noble, E. van Wyk, C. Ordóñez, C. Oke, and L. Pintér. 2019. Nature-based solutions for urban climate change adaptation: linking science, policy, and practice communities for evidence-based decision-making. BioScience 69(6):455-466. https://doi.org/10.1093/biosci/biz042
Friis, C., and J. Ø. Nielsen. 2019. Telecoupling: exploring landuse change in a globalised world. Springer, Cham, Switzerland. https://doi.org/10.1007/978-3-030-11105-2

Gómez-Baggethun, E., Å. Gren, D. N. Barton, J. Langemeyer, T. McPhearson, P. O'Farrell, E. Andersson, Z. Hamstead, and P. Kremer. 2013. Urban ecosystem services. Pages 175-251 in T. Elmqvist, M. Fragkias, J. Goodness, B. Güneralp, P. J. Marcotullio, R. I. McDonald, S. Parnell, M. Schewenius, M. Sendstad, K. C. Seto, and C. Wilkinson, editors. Urbanization, biodiversity and ecosystems services: challenges and opportunities. Springer Verlag, Dordrecht, The Netherlands. https://doi. org/10.1007/978-94-007-7088-1 11

Gorn, L., J. Kleemann, and C. Fürst. 2018. Improving the matrixassessment of ecosystem services provision - the case of regional land use planning under climate change in the region of Halle, Germany. Land 7(2):76. https://doi.org/10.3390/land7020076

Grimm, N. B., E. M. Cook, R. L. Hale, and D. M. Iwaniec. 2016. A broader framing of ecosystem services in cities: benefits and challenges of built, natural, or hybrid system function. Pages 203-212 in K. C.-Y. Seto, W. D. Solecki, and C. A. Griffith, editors. Handbook on urbanization and global environmental change. Routledge, London, UK.

Haase, D., S. Kabisch, A. Haase, E. Andersson, E. Banzhaf, F. Baró, M. Brenck, L. K. Fischer, N. Frantzeskaki, N. Kabisch, K. Krellenberg, P. Kremer, J. Kronenberg, N. Larondelle, J. Mathey, S. Pauleit, I. Ring, D. Rink, N. Schwarz, and M. Wolff. 2017. Greening cities - to be socially inclusive? About the alleged paradox of society and ecology in cities. Habitat International 64:41-48. https://doi.org/10.1016/j.habitatint.2017.04.005

Haase, D., N. Larondelle, E. Andersson, M. Artmann, S. Borgström, J. Breuste, E. Gomez-Baggethun, A. Gren, Z. Hamstead, R. Hansen, N. Kabisch, P. Kremer, J. Langemeyer, E. L. Rall, T. McPhearson, S. Pauleit, S. Qureshi, N. Schwarz, A. Voigt, D. Wurster, and T. Elmqvist. 2014. A quantitative review of urban ecosystem service assessments: concepts, models, and implementation. AMBIO 43:413-433. https://doi.org/10.1007/ s13280-014-0504-0

Haase, D., M. Wolff, and N. Schumacher. 2021. Mapping mental barriers that prevent the use of neighborhood green spaces. Ecology and Society 26(4):16. https://doi.org/10.5751/ES-12675-260416

Hansen, R., N. Frantzeskaki, T. McPhearson, E. Rall, N. Kabisch, A. Kaczorowska, J.-H. Kain, M. Artmann, and S. Pauleit. 2015. The uptake of the ecosystem services concept in planning discourses of European and American cities. Ecosystem Services 12:228-246. https://doi.org/10.1016/j.ecoser.2014.11.013

Healey, P. 1998. Collaborative planning in a stakeholder society. Town Planning Review 69(1):1-21. https://doi.org/10.3828/ tpr.69.1.h651u2327m86326p

Jacobs, J. M. 2012. Commentary-comparing comparative urbanisms. Urban Geography 33(6):904-914. https://doi. org/10.2747/0272-3638.33.6.904

Jennings, V., C. Johnson Gaither, and R. S. Gragg. 2012. Promoting environmental justice through urban green space access: a synopsis. Environmental Justice 5(1)1-7. https://doi. org/10.1089/env.2011.0007 
Juntti, M., and L. Lundy. 2017. A mixed methods approach to urban ecosystem services: experienced environmental quality and its role in ecosystem assessment within an inner-city estate. Landscape and Urban Planning 161:10-21. https://doi. org/10.1016/j.landurbplan.2017.01.002

Lang, D. J., A. Wiek, M. Bergmann, M. Stauffacher, P. Martens, P. Moll, M. Swilling, and C. J. Thomas. 2012. Transdisciplinary research in sustainability science: practice, principles, and challenges. Sustainability Science 7:25-43. https://doi.org/10.1007/ $\underline{\text { s11625-011-0149-X }}$

Langemeyer, J., and J. J. T. Connolly. 2020. Weaving notions of justice into urban ecosystem services research and practice. Environmental Science and Policy 109:1-14. https://doi. org/10.1016/j.envsci.2020.03.021

Marcus, L., and J. Colding. 2014. Toward an integrated theory of spatial morphology and resilient urban systems. Ecology and Society 19(4):55. https://doi.org/10.5751/ES-06939-190455

Markolf, S. A., M. V Chester, D. A. Eisenberg, D. M. Iwaniec, C. I. Davidson, R. Zimmerman, T. R. Miller, B. L. Ruddell, and H. Chang. 2018. Interdependent infrastructure as linked social, ecological, and technological systems (SETSs) to address lock-in and enhance resilience. Earth's Future 6(12):1638-1659. https:// doi.org/10.1029/2018EF000926

McPhearson, T., E. Andersson, T. Elmqvist, and N. Frantzeskaki. 2015. Resilience of and through urban ecosystem services. Ecosystem Services 12:152-156. https://doi.org/10.1016/j. ecoser.2014.07.012

McPhearson, T., S. T. A. Pickett, N. B. Grimm, J. Niemelä, M. Alberti, T. Elmqvist, C. Weber, D. Haase, J. Breuste, and S. Qureshi. 2016. Advancing urban ecology toward a science of cities. BioScience 66:198-212. https://doi.org/10.1093/biosci/ $\underline{\text { biw002 }}$

McPhearson, T., C. Raymond, N. Gulsrud, C. Albert, N. Coles, N. Fagerholm, M. Nagatsu, A. Olafsson, N. Soininen, and K. Vierikko. 2021. Radical changes are needed for transformations to a good Anthropocene. npj Urban Sustainability 1:5. https:// doi.org/10.1038/s42949-021-00017-X

Meerow, S., J. P. Newell, and M. Stults. 2016. Defining urban resilience: a review. Landscape and Urban Planning 147:38-49. https://doi.org/10.1016/j.landurbplan.2015.11.011

Nilsson, K. S. B., T. A. S. Nielsen, C. Aalbers, S. Bell, B. Boitier, J. P. J. P. Chery, C. Fertner, M. Groschowski, D. Haase, W. Loibl, S. Pauleit, M. Pintar, A. Piorr, J. Ravetz, M. Ristimäki, M. Rounsevell, I. Tosics, J. Westerink, and I. Zasada. 2014. Strategies for sustainable urban development and urban-rural linkages. European Journal of Spatial Development.

Norström, A. V., C. Cvitanovic, M. F. Löf, S. West, C. Wyborn, P. Balvanera, A. T. Bednarek, E. M. Bennett, R. Biggs, A. de Bremond, B. M. Campbell, J. G. Canadell, S. R. Carpenter, C. Folke, E. A. Fulton, O. Gaffney, S. Gelcich, J. B. Jouffray, M. Leach, M. Le Tissier, B. Martín-López, E. Louder, M. F. Loutre, A. M. Meadow, H. Nagendra, D. Payne, G. D. Peterson, B. Reyers, R. Scholes, C. I. Speranza, M. Spierenburg, M. Stafford-Smith, M. Tengö, S. van der Hel, I. van Putten, and H. Österblom. 2020.
Principles for knowledge co-production in sustainability research. Nature Sustainability 3:182-190. https://doi.org/10.1038/s41893-019-0448-2

Ostrom, E. 1999. Linking social and ecological systems: management practices and social mechanisms for building resilience. Ecological Economics 28(1):151-153.

Ostrom, E. 2009. A general framework for analyzing sustainability of social-ecological systems. Science 325 (5939):419-422. https://doi.org/10.1126/science.1172133

Palomo, I., M. R. Felipe-Lucia, E. M. Bennett, B. Martín-López, and U. Pascual. 2016. Disentangling the pathways and effects of ecosystem service co-production. Advances in Ecological Research 54:245-283. https://doi.org/10.1016/bs.aecr.2015.09.003

Pauleit, S., B. Ambrose-Oji, E. Andersson, B. Anton, A. Buijs, D. Haase, B. Elands, R. Hansen, I. Kowarik, J. Kronenberg, T. Mattijssen, A. Stahl Olafsson, E. Rall, A. P. N. van der Jagt, and C. Konijnendijk van den Bosch. 2019. Advancing urban green infrastructure in Europe: outcomes and reflections from the GREEN SURGE project. Urban Forestry and Urban Greening 40:4-16. https://doi.org/10.1016/j.ufug.2018.10.006

Pereira, L., N. Sitas, F. Ravera, A. Jimenez-Aceituno, and A. Merrie. 2019. Building capacities for transformative change towards sustainability: imagination in intergovernmental sciencepolicy scenario processes. Elementa: Science of the Anthropocene 7:35. https://doi.org/10.1525/elementa.374

Pierskalla, C. D., and M. E. Lee. 1998. An ecological perception model of leisure affordances. Leisure Sciences 20(1):67-79. https:// doi.org/10.1080/01490409809512265

Pu, B., and Y. Qiu. 2016. Emerging trends and new developments on urban resilience: a bibliometric perspective. Current Urban Studies 4(1):36-52. https://doi.org/10.4236/cus.2016.41004

Raymond, C. M., M. Giusti, and S. Barthel. 2018. An embodied perspective on the co-production of cultural ecosystem services: toward embodied ecosystems. Journal of Environmental Planning and Management 61(5-6):778-799. https://doi. org/10.1080/09640568.2017.1312300

Resilience Alliance. 2010. Assessing resilience in social-ecological systems: workbook for practitioners. Version 2.0.

Rigolon, A. 2016. A complex landscape of inequity in access to urban parks: a literature review. Landscape and Urban Planning 153:160-169. https://doi.org/10.1016/j.landurbplan.2016.05.017

Rittel, H. W. J., and M. M. Webber. 1973. Dilemmas in a general theory of planning. Policy Sciences 4(2):155-169. https://doi. org/10.1007/BF01405730

Romice, O., A. Feliciotti, and S. Porta. 2018. Urban form resilience urban design practice: masterplanning for change. International Forum on Urbanism: Urban form resilience urban design practice: masterplanning for change. School of Architecture, Barcelona, Spain. https://doi.org/10.3390/IFOU2018-05976

Sellberg, M. M., A. V. Norström, G. D. Peterson, and L. J. Gordon. 2020. Using local initiatives to envision sustainable and resilient food systems in the Stockholm city-region. Global Food Security 24:100334. https://doi.org/10.1016/j.gfs.2019.100334 
Sellberg, M. M., P. Ryan, S. T. Borgström, A. V. Norström, and G. D. Peterson. 2018. From resilience thinking to resilience planning: lessons from practice. Journal of Environmental Management 217:906-918. https://doi.org/10.1016/j.jenvman.2018.04.012

Seto, K. C., A. Reenberg, C. G. Boone, M. Fragkias, D. Haase, T. Langanke, P. Marcotullio, D. K. Munroe, B. Olah, and D. Simon. 2012. Urban land teleconnections and sustainability. Proceedings of the National Academy of Sciences 109 (20):7687-7692. https://doi.org/10.1073/pnas.1117622109

Seymour, M. 2012. Just sustainability in urban parks. Local Environment 17(2):167-185. https://doi.org/10.1080/13549839.2011.646968

Sirianni, C. 2007. Neighborhood planning as collaborative democratic design. Journal of the American Planning Association 73(4):373-387. https://doi.org/10.1080/01944360708978519

Spangenberg, J. H., C. von Haaren, and J. Settele. 2014. The ecosystem service cascade: further developing the metaphor. Integrating societal processes to accommodate social processes and planning, and the case of bioenergy. Ecological Economics 104:22-32. https://doi.org/10.1016/j.ecolecon.2014.04.025

Star, S. L., and J. R. Griesemer. 1989. Institutional ecology, 'translations' and boundary objects: amateurs and professionals in Berkeley's Museum of Vertebrate Zoology, 1907-39. Social Studies of Science 19(3):387-420. https://doi.org/10.1177/03063$\underline{1289019003001}$

Stedman, R. C. 2016. Subjectivity and social-ecological systems: a rigidity trap (and sense of place as a way out). Sustainability Science 11(6):891-901. https://doi.org/10.1007/s11625-016-0388y

Taff, B. D., J. Benfield, Z. D. Miller, A. D'Antonio, and F. Schwartz. 2019. The role of tourism impacts on cultural ecosystem services. Environments 6(4):43. https://doi.org/10.3390/ environments6040043

Tengö, M., R. Hill, P. Malmer, C. M. Raymond, M. Spierenburg, F. Danielsen, T. Elmqvist, and C. Folke. 2017. Weaving knowledge systems in IPBES, CBD and beyond-lessons learned for sustainability. Current Opinion in Environmental Sustainability 26-27:17-25. https://doi.org/10.1016/j.cosust.2016.12.005

Tidball, K., N. Frantzeskaki, and T. Elmqvist. 2016. Traps! An introduction to expanding thinking on persistent maladaptive states in pursuit of resilience. Sustainability Science 11:861-866. https://doi.org/10.1007/s11625-016-0398-9

Turnhout, E. 2009. The effectiveness of boundary objects: the case of ecological indicators. Science and Public Policy 36 (5):403-412. https://doi.org/10.3152/030234209X442007

Turnhout, E., T. Metze, C. Wyborn, N. Klenk, and E. Louder. 2020. The politics of co-production: participation, power, and transformation. Current Opinion in Environmental Sustainability 42:15-21. https://doi.org/10.1016/j.cosust.2019.11.009

Tzoulas, K., K. Korpela, S. Venn, V. Yli-Pelkonen, A. Kaźmierczak, J. Niemelä, and P. James. 2007. Promoting ecosystem and human health in urban areas using green infrastructure: a literature review. Landscape and Urban Planning 81(3):167-178. https://doi.org/10.1016/j.landurbplan.2007.02.001

van den Bosch, M., and Å. O. Sang. 2017. Urban natural environments as nature-based solutions for improved public health: a systematic review of reviews. Environmental Research 158:373-384. https://doi.org/10.1016/j.envres.2017.05.040

Walker, B. H., S. R. Carpenter, J. Rockstrom, A.-S. Crépin, and G. D. Peterson. 2012. Drivers, "slow" variables, "fast" variables, shocks, and resilience. Ecology and Society 17(3):30. https://doi. org/10.5751/ES-05063-170330

Walker, W. 2000. Entrapment in large technology systems: institutional commitment and power relations. Research Policy 29(7-8):833-846. https://doi.org/10.1016/S0048-7333(00)00108-6

Webster, C. 2002. Property rights and the public realm: gates, green belts, and Gemeinschaft. Environment and Planning B: Planning and Design 29(3):397-412. https://doi.org/10.1068/ $\underline{\text { b2755r }}$

Webster, C. 2007. Property rights, public space and urban design. Town Planning Review 78(1):81-101. https://doi.org/10.3828/ tpr.78.1.6

Wolff, M. 2021. Taking one step further — advancing the measurement of green and blue area accessibility using spatial network analysis. Ecological Indicators 126:107665. https://doi. org/10.1016/j.ecolind.2021.107665 
Appendix 1. Definition and usage of resilience.

Grounded in scholarship on complex adaptive systems (e.g. Levin 1999, Scheffer et al. 2001) and social-ecological systems (Berkes and Folke 1998, Ostrom 1999) we use a systems approach for analysing and operationalising resilience. This tradition recognises two types of resilience, general and specific resilience. General resilience points to the existence of different self-reinforcing system regimes, and the possibility to shift from one regime to another (e.g. Scheffer et al. 2001). We follow Elmqvist et al. 2019 in that we relate resilience to different development trajectories rather than regimes in the sense of stabile states. Urban (general) resilience calls for a definition of the core properties of 'urban', which is open to discussion. One trajectory could for example be defined as a globalized, fossil-fuelled growing city with established governance structures and processes, characterized by a certain metabolism and resident livelihoods and lifestyles. Specific resilience is more heterogeneous and concise, as it looks at specific properties and processes of a system and their response to change and pressures (e.g. Walker and Salt 2012). Specific resilience may for example relate to the ecological resilience of an urban ecosystem or the adaptive or transformative capacity of a certain group of actors. The context of specific resilience can be described in terms of drivers of change, controlling (often 'slow') variables (often the features defining the regime discussed under general resilience) and feedbacks between these and across scales (Gunderson and Holling 2002, Walker et al. 2012). In line with this contextual understanding of specific resilience, complex problems can be analysed as multiple more or less resilient factors interact. Peterson et al. (1999) demonstrated this for multiple scales, and we extend the same logic to multiple domains.

Drivers of change can act directly on a specific aspect of a system, or they could exert pressure on the slow variables that in turn influence this aspect. Thus, we add the resilience of the slow variables themselves as a second layer to our cross scale analysis of resilience. As we will describe, high level, systemic factors such as built capital and institutions, may often impose quite resilient barriers to breaking free from and transforming lock-in situations and inhibiting contexts. In line with the above reasoning, and different from how it is sometimes used in the public discourse (e.g. Elmqvist et al. 2019), we hold resilience to be a nonnormative concept and thus in itself not suited to making decisions about desirability. The basic question 'resilience of what' sets the baseline, which can be further elaborated by evaluative frameworks like justice or sustainability (e.g. Langemeyer and Connolly 2020)

\section{LITERATURE CITED}

Berkes, F., and C. Folke. 1998. Linking social and ecological systems: management practices and social mechanisms for building resilience. Cambridge University Press, Cambridge.

Gunderson, L. H., and C. S. Holling. 2002. Panarchy. Understanding transformations in human and natural systems. Island Press, Washington D.C., USA.

Langemeyer, J., and J. J. T. Connolly. 2020. Weaving notions of justice into urban ecosystem services research and practice. Environmental Science and Policy 109:1-14.

Levin, S. A. 1999. Fragile dominion. Perseus Publishing, Cambridge, USA.

Ostrom, E. 1999. Linking social and ecological systems: Management practices and social mechanisms for building resilience. Ecological Economics 28(1):151-153. 
Scheffer, M., S. Carpenter, J. A. Foley, C. Folke, and B. Walker. 2001. Catastrophic shifts in ecosystems. Nature 413(6856):591-596.

Walker, B. H., S. R. Carpenter, J. Rockstrom, A.-S. Crépin, and G. D. Peterson. 2012. Drivers, "Slow" Variables, "Fast" Variables, Shocks, and Resilience. Ecology and Society 17(3): art30.

Walker, B., and D. Salt. 2012. Resilience thinking: sustaining ecosystems and people in a changing world. Island Press, Washington DC, USA. 
Appendix 2. Typology and description of the participatory co-production processes.

Co-production is a complex process that has been categorized and described using multiple different variables. However, for simplicity we limit our differentiation to three axes capturing the main differences of our cases: 1) Level of stakeholder engagement, ranging from consultation to collaboration (Rowe and Frewer 2005, Mobjörk 2010); 2) Primary outcome, in our cases awareness raising, capacity building and informing policy (Luederitz et al. 2017); and 3) Process mandate, with in our study the three types independent, consecutive and embedded (in resonance with the policy arenas and cultures descibed in e.g. Pohl 2008). Consultation means obtaining feedback from and providing adequate information to interested third parties on relevant aspects of the design, methodologies, analysis and results of a project. Collaboration instead means working in partnership with individuals, or groups, in relevant aspects of the co-production process, including the development of alternative methods and the identification of preferred solutions or outcomes to satisfy participant needs. There are multiple hybrid versions in between collaboration and consultation, and sequential, multi-step processes like our three cases may mix and move between the two as they unfold.

Independent means driven and owned by the researchers (as in Halle), consecutive that the process is a semi-autonomous, researcher owned process connected to parallel or earlier processes (with varied ownership) (as in Stockholm), and embedded that the process was coowned and formed part of another process owned by someone other than the researchers (ass was the case in Barcelona).

\section{LITERATURE CITED}

Luederitz, C., N. Schäpke, A. Wiek, D. J. Lang, M. Bergmann, J. J. Bos, S. Burch, A. Davies, J. Evans, A. König, M. A. Farrelly, N. Forrest, N. Frantzeskaki, R. B. Gibson, B. Kay, D. Loorbach, K. McCormick, O. Parodi, F. Rauschmayer, U. Schneidewind, M. Stauffacher, F. Stelzer, G. Trencher, J. Venjakob, P. J. Vergragt, H. von Wehrden, and F. R. Westley. 2017. Learning through evaluation - A tentative evaluative scheme for sustainability transition experiments. Journal of Cleaner Production 169:61-76.

Mobjörk, M. 2010. Consulting versus participatory transdisciplinarity: A refined classification of transdisciplinary research. Futures 42(8):866-873.

Pohl, C. 2008. From science to policy through transdisciplinary research. Environmental Science \& Policy 11:46-53.

Rowe, G., and L. J. Frewer. 2005. A typology of public engagement mechanisms. Science, Technology, \& Human V alues 30(2):251-290. 